\title{
EFEKTIVITAS IMPLEMENTASI PROGRAM GENTASIBU DI KELURAHAN BEGADUNG KECAMATAN NGANJUK KABUPATEN NGANJUK
}

\author{
*Heylen Amildha Yanuarita ${ }^{1)}$, Titis Sakra ${ }^{2)}$ \\ 1) Program Studi Administrasi Publik Universitas Kadiri, Indonesia \\ 2) Program Studi Administrasi Publik Universitas Kadiri, Indonesia \\ *Email Korespondensi : heylenay@unik-kediri.ac.id
}

\begin{abstract}
Abstrak
Salah satu alternatif penanggulangan gizi buruk di Puskesmas Nganjuk adalah dengan menjalankan program Gerakan Pengentasan Gizi Buruk (GENTASIBU). Program Gentasibu adalah serangkaian kegiatan yang dilakukan secara terpadu, terintegrasi dan berkesinambungan untuk memelihara dan meningkatkan status gizi masyarakat dalam bentuk upaya promotif, preventif, kuratif maupun rehabilitatif. Kelompok sasaran dalam program Gentasibu adalah semua balita yang mempunyai indeks berat badan yang terlihat sangat kurus, untuk anak usia 6-59 bulan. Kegiatan program Gentasibu di pos pelayanan seperti pemeriksaan klinis dan pengobatan oleh dokter, pengukuran antroperi dan konseling oleh petugas gizi, pemberdayaan keluarga oleh Tim Penggerak PKK, pemberian makanan tambahan (PMT) dan vitamin, serta pendampingan orang tua balita oleh kader pendamping. Pada pelaksanaannya, masyarakat atau sasaran program sudah cukup paham tentang program Gentasibu. Penelitian ini menggunakan jenis penelitian deskriptif dengan pendekatan kualitatif. Teknik pengumpulan data yang digunakan yaitu observasi, wawancara, dokumentasi. Hasil penelitian menunjukkan sudah cukup baik sosialisasi yang dilakukan oleh pelaksana program kepada masyarakat. Dalam sosialisasi, penyampaian materi program Gentasibu kepada kelompok sasaran dapat diterima dengan baik. Sumber daya manusia dalam pelaksanaan program Gentasibu masih kurang dalam segi jumlah petugas gizi Puskesmas. Dalam pelaksanaan program Gentasibu wewenang berada pada petugas gizi Puskesmas.
\end{abstract}

Kata Kunci: Efektivitas; Implementasi; Gentasibu.

\begin{abstract}
One alternative to overcome malnutrition in Begadung Village, Nganjuk District, Nganjuk Health Center is running the Malnutrition Eradication Movement (GENTASIBU) program. The Gentasibu Program is a series of activities carried out in an integrated, integrated and continuous manner to maintain and improve the nutritional status of the community in the form of promotive, preventive, curative and rehabilitative efforts. The target groups in the Gentasibu program are all toddlers who have a weight index that looks very thin, for children aged 6-59 months. Gentasibu program activities at the service post such as clinical examination and treatment by doctors, antroperian measurement and counseling by nutrition officers, family empowerment by $P K K$ Mobilizing Team, supplementary feeding (PMT) and vitamins, and mentoring of toddlers' parents by supporting cadres. In its implementation, the community or the target of the program was quite
\end{abstract}


familiar with the Gentasibu program. This research uses descriptive research with a qualitative approach. Data collection techniques used are observation, interviews, documentation. The results of the study showed that socialization was carried out quite well by program implementers to the community. In the socialization, the presentation of Gentasibu program material to the target group was well received. Human resources in the implementation of the Gentasibu program are still lacking in terms of the number of Puskesmas nutrition workers. In the implementation of the Gentasibu program the authority lies with the Puskesmas nutrition officer.

Keywords: Effectiveness; Implementation; Gentasibu.

\section{PENDAHULUAN}

Program Gerakan Pengentasan Gizi Buruk (GENTASIBU) adalah salah satu program unggulan Kabupaten Nganjuk yang dilaksanakan diseluruh kecamatan, salah satunya di terapkan di Puskesmas Induk Kecamatan Nganjuk yang bertujuan meningkatkan kualiatas pelayanan kesehatan bagi penderita gizi buruk anak balita di Kecamatan Nganjuk. Inovasi pelayanan yang diberikan yaitu Pemberian Makanan Tambahan (PMT), obat-obatan, vitamin dan pendampingan terhadap orangtua balita penderita gizi buruk. Dalam jangka pendek program ini diharapkan membantu masyarakat yang memiliki anak penderita gizi buruk agar dapat disembuhkan, sedangkan dalam jangka panjang GENTASIBU merupakan investasi sumber daya manusia agar generasi berikutnya tidak ada lagi kasus anak balita yang menderita gizi buruk.

Selama ini kader posyandu lebih sering menjadi pelaksana kegiatan saja, Bukan sebagai pengelola posyandu, karena merekalah yang paling memahami kondisi kebutuhan masyarakat di wilayahnya (Afan, 2018). Disamping itu, kader dianjurkan untuk menekankan perhatian permasalahan gizi masyarakat, khususnya pada Ibu hamil, Ibu menyusui, serta pada bayi dan balita. Hal ini dikarenakan banyak ditemukannya kasus kemunduran gizi di masyarakat terutama masyarakat miskin (Afan, 2018). Hal yang dapat dilakukan oleh kader dalam berpartisipasi menurunkan angka gizi buruk dimasyarakat yaitu: penimbangan balita dan pencatatan hasil timbangan, penyuluhan atas dasar hasil penimbangan, memberikan penyuluhan pedoman pemberian makan balita, dan melakukan kunjungan rumah untuk memantau kesehatan balita (Agrinadhiar, 2011). Peran kader Gentasibu selain bertugas mendampingi penderita gizi buruk, juga sebagai 
menggerakkan masyarakat untuk datang menimbang berat badan dan mengukur tinggi badan, menilai nafsu makan dan asupan makan balita, menanyakan dan anjurkan orang tua tidak merokok, dan membimbing orang tua balita mengenali masalah dan memecahkannya. Perubahan jumlah bayi dengan gizi buruk menjadi gizi baik merupakan keberhasilan berkat kerjasama kader dan petugas kesehatan di dalam penanganan gizi buruk, khususnya di Kecamatan Nganjuk. Kecamatan Nganjuk sendiri terdapat beberapa balita yang dapat dikategorikan sebagai gizi kurang atau gizi buruk.

Tim atau Kader pelaksanaan program GENTASIBU di Kelurahan Begadung sangat berupaya semaksimal mungkin untuk melaksanakan dan mensukseskan program ini. Namun, ternyata program ini berjalan tidak semudah yang dibayangkan. Tak jarang para orang tua menolak anaknya dikategorikan sebagai kurang gizi, dengan alasan mereka adalah orang mampu yang hidup serba berkecukupan. Serta terdapat pula orang tua yang tidak hadir dalam pertemuan penyuluhan tentang gizi, pengukuran dan penimbangan berat badan balita dengan alasan malu atau bahkan karena tidak ada kendaraan. Menghadapi berbagai sifat dan sikap para orang tua yang demikian maka disini tim dan kader pelaksana bekerja lebih keras lagi untuk meyakinkan para orang tua yang tidak aktif dalam keikutsertaan program Gentasibu.

Penelitian yang dilakukan oleh (Rahmawati, 2017) menunjukkan keberhasilan program Gentasibu menekan angka gizi buruk dengan sangat signifikan sejak pertama kali diimplementasikan. Program Gentasibu adalah serangkaian kegiatan yang dilakukan secara terpadu, terintegrasi dan berkesinambungan untuk memelihara dan meningkatkan status gizi masyarakat dalam bentuk upaya promotif, preventif, kuratif maupun rehabilitatif. Oleh karena itu penelitian ini bertujuan untuk menganalisis bagaimana efektivitas implementasi program gentasibu di Kelurahan Begadung Kecamatan Nganjuk Kabupaten Nganjuk. Setelah itu, peneliti juga melakukan analisis tentang faktor apa saja yang mendukung dan menghambat efektivitas implementasi program gentasibu di Kelurahan Begadung Kecamatan Nganjuk Kabupaten Nganjuk. 


\section{TINJAUAN PUSTAKA}

Efektivitas adalah seberapa baik pekerjaan yang dilakukan, sejauh mana orang menghasilkan keluaran sesuai dengan yang diharapkan (Astuti \& Dharmadiaksa, 2014). Hal ini berarti bahwa apabila suatu pekerjaan dapat diselesaikan dengan perencanaan, baik dalam waktu, biaya maupun mutunya, maka dapat dikatakan efektif. Selain itu, efektivitas adalah hubungan antara output dan tujuan (Elis Sriani \& Sasmito, 2018). Artinya efektivitas merupakan ukuran seberapa jauh tingkat output, kebijakan dan prosedur dari organisasi mencapai tujuan yang ditetapkan. Secara pengertian teoritis atau praktis, tidak ada persetujuan yang universal mengenai apa yang dimaksud dengan "Efektivitas". Definisi lain dari efektivitas adalah penilaian yang dibuat sehubungan dengan prestasi individu, kelompok, dan organisasi (Sahputra, 2015).

Fenomena public policy itu sudah ada sejak timbulnya politics atau kegiatan politik. Seperti yang kita ketahui bersama bahwa kegiatan politik sudah ada sejak beberapa abad sebelum masehi, serta sebagai ilmu politik pun sudah mulai pada jaman Yunani, yaitu bahwa beberapa ratus tahun sebelum masehi sudah dipelajari orang. Pada waktu itu banyak keputusan-keputusan politik, ketetapan pejabat dan peraturan-peraturan penguasa, serta keputusan-keputusan mengenai kepentingan umum public interest (Rusydi, 2015). Hanya saja, semuanya itu belumlah dikenal sebagai public policy sebagai yang kita ketahui sekarang ini.

Pada jaman Yunani kuno public policy yang pertama yaitu merupakan kode resmi, dihasilkan oleh Kota Mesopotamia pada abad 21 sebelum masehi (Suhelmi, 2001). Selanjutnya dikenal adanya "Kode Hamurabi" (The Code of Hamurabi), kode ini meliputi prosedur-prosedur kriminal, undang-undang pemilikan, perdagangan, hubungan keluarga dan perkawinan, tarif tabib, dan apa yang kita kenal sekarang dengan pertanggung jawaban publik (Dunn, 2015). Kebijakan pemerintah itu adalah hubungan unit pemerintah dengan sebuah lingkungan (Rian, 2017). Kebijakan pemerintah itu adalah apa saja yang ditetapkan oleh pemerintah untuk dilakukan atau tidak dilakukan (Dye, 2013). Sementara itu kebijakan publik adalah sebuah list pilihan suatu tindakan yang saling terhubung yang disusun oleh sebuah instansi atau pejabat pemerintah antara lain dalam sebuah bidang 
pertahanan, kesehatan, pendidikan, kesejahteraan, pengendalian kriminalitas, dan sebuah pembangunan perkotaan (Dunn, 2015).

Implementasi adalah kegiatan untuk mendistribusikan keluaran kebijakan (to deliver policy output) yang dilakukan oleh para implementator kepada kelompok sasaran (target group) sebagai upaya untuk mewujudkan kebjakan (Purwanto, 2012). Pengertian implementasi yang lain merupakan suatu proses yang dinamis, dimana pelaksana kebijakan melakukan suatu aktivitas atau kegiatan, sehingga pada akhirnya akan mendapatkan suatu hasil yang sesuai dengan tujuan atau sasaran kebijakan itu sendiri (Karigas et al., 2018).

Didalam pelaksanaan kebijaksanaan pemerintah, disamping memperhatikan faktor-faktor yang perlu ditanggulangi dapat menyebabkan kegagalan, maka sangat penting memperhatikan pula faktor-faktor yang dapat mendorong keberhasilan daripada pelaksanaan kebijaksanaan itu. Faktor-faktor ini memang merupakan syarat untuk keberhasilan suatu kebijaksanaan. Oleh karena itu haruslah diusahakan terwujudnya semaksimal mungkin.

Faktor-faktor untuk keberhasilan pelaksanaan kebijaksanaan tersebut adalah :

- Persetujuan, dukungan dan kepercayaan rakyat. Tiga hal ini, seperti telah dikemukakan diatas, yang dapat menimbulkan partisipasi masyarakat, yang benar- benar diperlukan untuk pelaksanaan kebijaksanaan.

- Isi dan tujuan kebijaksanaan haruslah dimengerti secara jelas terlebih dahulu. Berhubung dengan itu maka pelaksana kebijaksanaan harus mampu melakukan interprestasi terhadap kebijaksanaan yang tepat sehingga mempunyai persepsi seperti yang dikehendaki oleh pembentuk kebijaksanaan.

- Pelaksana haruslah mempunyai cukup formasi, terutama mengenai kondisi dan kesadaran masyarakat yang dikenai kebijaksanaan itu.

- Pembagian pekerjaan yang efektif dalam pelaksanaan. Hal ini berarti perlu pengorganisasian yang baik, dengan : 
a. Diferensiasi kegiatan secara horizontal beserta koordinasi yang baik.

b. Diferensiasi kegiatan secara vertikal dengan pengawasnya yang efektif.

- Pembagian kekuasaan dan wewenang (decentralization) yang rasional dalam pelaksanaan kebijaksanaan.

- Pemberian tugas-tugas dan kewajiban - kewajiban (deconcentration) yang memadai dalam pelaksanaan kebijaksanaan.

Program Gerakan Pengentasan Gizi Buruk (Gentasibu) adalah salah satu program unggulan Kabupaten Nganjuk yang dilaksanakan diseluruh kecamatan, salah satunya di terapkan di Puskesmas Kecamatan Nganjuk yang bertujuan meningkatkan kualitas pelayanan kesehatan bagi penderita gizi buruk anak balita di Kecamatan Nganjuk. Inovasi pelayanan yang diberikan yaitu Pemberian Makanan Tambahan (PMT), obat-obatan, vitamin dan pendampingan terhadap orangtua balita penderita gizi buruk. Peraturan Bupati tentang Upaya Percepatan Penurunan angka Kematian Ibu dan Bayi di Kabupaten Nganjuk. Beberapa regulasi tersebut antara lain :

1. Kepala Puskesmas ikut memantau langsung dan bertanggungjawab terhadap pelaksanaan program GENTASIBU (Gerakan Pengentasan Gizi Buruk) dan GERDARISTI (Gerakan Pendampingan Ibu Hamil dan Bayi Risiko Tinggi) ditempat berlangsungnya pelayanan.

2. Kepala Puskesmas PONED (Pelayanan Obstetrik Neonatal Emergency Dasar) bertanggung jawab terhadap pelaksanaan pelayanan kesehatan sesuai standar yang ada.

\section{METODE PENELITIAN}

Jenis penelitian yang digunakan dalam penulisan skripsi ini adalah penelitian deskriptif dengan jenis kualitatif. Penelitian deskriptif adalah penelitian yang digunakan untuk mendeskripsikan dan menjawab persoalan-persoalan suatu fenomena atau peristiwa yang terjadi saat ini, baik tentang fenomena dalam variabel tunggal maupun perbandingan berbagai variable (Setyosari, 2016). Adapun Penelitian dengan pendekatan kualitatif 
adalah pendekatan penelitian yang pengambilan datanya dalam bentuk narasi, cerita detail, ungkapan dan bahasa asli hasil konstruksi para responden atau informan, tanpa ada evaluasi dan interpretasi dari peneliti (Wijaya, 2019). Pendekatan penelitian kualitatif adalah metode penelitian yang berlandaskan pada filsafat postpositivisme. Filsafat ini sering juga disebut sebagai paradigma interpretatif dan konstruktif, yang memandang realitas sosial sebagai sesuatu yang utuh, kompleks, dinamis, penuh makna, dan hubungan gejala bersifat interaktif (Anggito \& Setiawan, 2018).

Penelitian yang dilakukan ini mengambil lokasi di Lingkungan Kelurahan Begadung, Kecamatan Nganjuk, Kabupaten Nganjuk. Pemilihan lokasi ini dengan pertimbangan sebagai berikut :

1. Di lingkungan Kelurahan Begadung, Kecamatan Nganjuk, Kabupaten Nganjuk terdapat beberapa balita yang dapat dikategorikan sebagai gizi buruk.

2. Dari hasil penelitian pada observasi awal bahwa adanya pro dan kontra antara orang tua balita dengan petugas atau kader PKK selaku pelaku kegiatan program gerakan pengentasan gizi buruk.

3. Sangat antusiasnya kader PKK atau pelaku kegiatan program pengentasan gizi buruk dalam menjalankan tugasnya.

Teknik penentuan informan menggunakan teknik purposive, dengan pertimbangan Puskesmas tersebut menjadi tumpuan masyarakat dalam meningkatkan gizi balita di daerah tersebut. Sudah tentu informan kunci akan ditelusuri berdasarkan luas sempitnya pengetahuan informan terhadap data yang dimaksudkan. Adapun teknik pengumpulan data menggunakan teknik observasi terhadap luas sempitnya permasalahan yang terkait dengan fenomena penelitian. Disamping itu dalam pengumpulan data juga digunakan teknik wawancara, sebab tidak semua data dapat dijaring hanya dengan observasi. Mengingat dalam kegiatan juga diperlukan berbagai sumber informasi yang bersifat dokumen, maka dokumentasi juga sebagai metode pengumpulan data.

Analisis adalah upaya yang dilakukan dengan jalan bekerja dengan data, mengorganisasikan data, memilah-milahnya menjadi satuan yang dapat dikelola, mensintesiskannya, mencari dan menemukan pola, menemukan apa yang penting dan apa 
yang dipelajari, dan memutuskan apa yang dapat diceritakan pada orang lain (Martono, 2010). Pada saat wawancara peneliti sudah melakukan analisis terhadap jawaban yang diwawancarai. Bila jawaban yang diwawancarai setelah dianalisis terasa belum memuaskan, maka peneliti akan melanjutkan lagi sampai tahap tertentu hingga diperoleh data yang dianggap kredibel. Selain itu, aktifitas dalam analisis data kualitatif dilakukan secara interaktif dan berlangsung secara terus menerus sampai tuntas sehingga datanya sudah jenuh.

Teknik analisis data yang digunakan dalam penelitian ini adalah analisis kualitatif yaitu mencakup pengumpulan data, reduksi data, penyajian data dan penarikan kesimpulan (Kasiram, 2010). Teknik analisis data dalam peneltian kualitatif meliputi : Pengumpulan data, mengolah dan mempersiapkan data untuk dianalisis (Martono, 2010). Langkah ini melibatkan transkrip wawancara, men-scanning materi, mengetik data lapangan atau memilah-milah dan menyusun data tersebut kedalam jenis-jenis yang berbeda tergantung pada sumber informasi.

Reduksi data merupakan suatu bentuk analisis yang menggolongkan, mengarahkan, membuang yang tak perlu dan mengorganisasikan data-data yang telah di reduksi memberikan gambaran yang lebih tajam tentang hasil pengamatan menjaditema. Penyajian Data (Data Display) penyajian data merupakan analisis dalam bentuk matrik, network, cart, atau grafis. Pada penelitian kualitatif, penyajian data dilakukan dalam bentuk uraian singkat, tabel, bagan dan hubungan antar kategori. Melalui penyajian data tersebut, maka data terorganisasikan, dan tersusun sehingga akan semakin mudah dipahami (Rijali, 2019).

Penarikan Kesimpulan (Conclusion Drawing/Verivication) merupakan penarikan kesimpulan dan verifikasi. Kesimpulan awal yang dikemukakan masih bersifat sementara, dan akan berubah apabila tidak ditemukan bukti- bukti kuat yang mendukung tahap pengumpulan berikutnya. Kesimpulan dalam penelitian kualitatif dapat menjawab rumusan masalah yang dirumuskan sejak awal. Secara skematis proses pengumpulan data, reduksi data, penyajian data, dan penarikan kesimpulan dapat digambarkan sebagai berikut: 


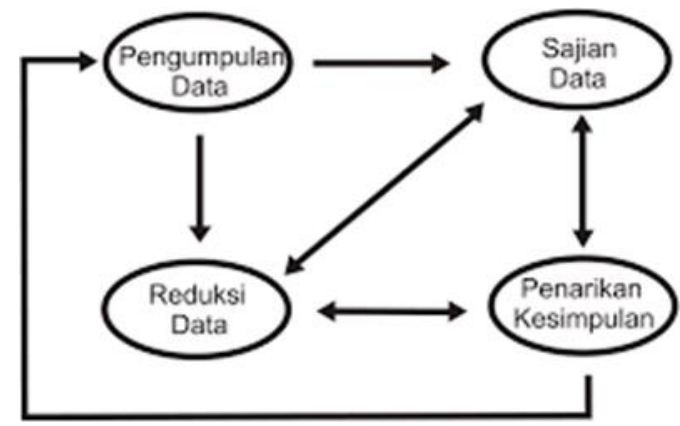

Gambar 3.1. Model Interaktif menurut Miles dan Huberman

(Saldana, 2014)

\section{HASIL DAN PEMBAHASAN}

Kemunculan gagasan inovatif Gentasibu diawali ketika inovator yang merupakan istri bupati sebagai penggagas mengikuti acara pertemuan istri bupati Se- Indonesia di Jakarta, Ibu Ani Yudhoyono sebagai pemateri memberikan pertanyaan tentang jumlah gizi buruk. Kemudian dilanjutkan dengan dikeluarkannya Surat Keputusan Bupati tentang pembentukan tim gerakan pengentasan gizi buruk (GENTASIBU) yang memberi kekuatan hukum bagi GENTASIBU dan akan mengarahkan jalanya GENTASIBU secara sustainable. Pasca dilegalkan, kunci sukses selanjutnya ada pada kader yang secara sukarela ikhlas tanpa pamrih untuk secara sadar diri turut berupaya menurunkan angka gizi buruk, seolah-olah sudah menjadi prinsip, sebisa mungkin balita gizi buruk harus disembuhkan.

Dalam implementasi Surat Keputusan Bupati tentang Gentasibu di Kelurahan Begadung Kecamatan Nganjuk banyak menghadapi tantangan, salah satunya banyak masyarakat yang memiliki balita merasa tersinggung, karena mereka para orang tua sudah memberikan sesuatu yang terbaik buat anaknya sesuai dengan kemampuan mereka. Namun masih dibilang anak tersebut tergolong gizi buruk. Dalam hal ini peran bidan cukup besar untuk selalu mensosialisasikan tentang gizi yang baik dan harus diberikan pada balita. Hal ini dapat terjadi karena ketidak tahuan para orang tua tentang gizi, tidak harus mahal untuk yang bergizi, namun pengetahuan tentang gizi memang harus disosialiusasikan kepada masyarakat. Oleh karena itu dukungan, peran, dan partisipasi 
bidan yang dibantu petugas kesehatan di Kelurahan Begadung untuk mensukseskan Gentasibu sangat besar.

Dengan demikian, segala kegiatan yang dilakukan oleh bidan dan pegawai patut diacungin jempol. Mereka melakukan hal tersebut karena panggilan sebagai orang yang tahu dan terlibat langsung dengan kesehatan, tahu tentang dampak dan akibat ke depan dari orang yang terkena gizi buruk. Partisipasi aktif dari orang-orang yang tahu tentang kesehatan khususnya tentang gizi buruk dalam mensosialisasikan tentang gizi buruk akhirnya secara perlahan tapi pasti membuahkan hasil. Hal ini terbukti para orang tua balita banyak yang mendukung dan dengan suka rela untuk mendekat pada aparat kesehatan untuk mendapatkan layanan tentang gizi buruk.

Oleh karena itu pemerintah melalui Puskesmas sebagai lembaga yang berkecimpung langsung dengan masyarakat di pedesaan memprogramkan, merancang dan melaksanakan kegiatan Gentasibu tersebut secara terstruktur, terkoordinir dan bekerja sama dengan aparat desa/kelurahan pedesaan untuk terus memantau dan melaksanakan kegiatan Gentasibu tersebut.

Program Gerakan Pengentasan Gizi Buruk terbukti mampu mengurangi balita penderita gizi buruk. Sebelum ada program Gentasibu tersebut, jumlah penderita balita gizi buruk di kabupaten ini mencapai 524 anak, dan dengan program itu, jumlah penderita terus menurun. Selain terus menggalakkan program Gentasibu, pemerintah juga terus memberikan pemahaman kepada seluruh keluarga balita yang menderita gizi buruk. Dari berbagai laporan yang masuk, keluarga para balita itu diketahui masih minim pengetahuan tentang penanganan balita yang mengalami gizi buruk.

Kendalanya pada tingkat pendidikan keluarga yang masih rendah. Rata-rata balita yang mengalami gizi buruk, tingkat pendidikan orang tuanya terbatas. Tidak hanya faktor pendidikan saja, namun juga kepedulian keluarga tentang peningkatan kualitas makan untuk balita yang juga rendah. Hal tersebut juga dip[engaruhi oleh faktor ekonomi keluarga. Dalam menjalankan program ini telah bekerjasama dengan sejumlah tim atuapun organisasi masyarakat, seperti Tim Penggerak PKK Kabupaten Nganjuk, kumpulan pengajian, dan organisasi sosial lainnya. 
Faktor Penghambat Implementasi Program Gentasibu di Kelurahan Begadung, Kecamatan Nganjuk, Kabupaten Nganjuk Dalam Program Gerakan Pengentasan Gizi Buruk pada Kelurahan Begadung kali ini faktor penghambatnya adalah dari pihak orang tua balita penyandang gizi buruk. Tak sedikit dari mereka kurang setuju bilamana anaknya dikategorikan kurang gizi atau gizi buruk. Karena kurangnya pendidikan menjadi salah satu faktor, mereka tersinggung dan mereka menganggap petugas menganggap rendah mereka karena petugas memiliki keluarga yang sehat. Tidak hanya itu, salah seorang keluarga balita yang memiliki taraf pendidikan dan materi lebih juga tak terima anaknya dikategorikan kurang gizi. Namun dengan kegigihan dan usaha petugas akhirnya mereka bisa memahami dan mau mengikuti kegiatan tersebut.

Dalam program ini banyak faktor pendukung atau faktor faktor yang menunjang keberhasilan program tersebut. Antaranya adalah: Dalam hal ini pemerintah menduduki peran penting dalam berjalannya sebuah program. Dimana Pemerintah yang selalu memperbaiki peraturan-peraturan yang mengatur tentang program gerakan pengentasan gizi buruk serta memfasilitasi sarana dan prasarana penunjang program tersebut. Pemerintah yang selalu mengawasi jalannya sebuah program akan menjadi faktor yang sangat mendukung keberhasilan. Karena, kebijakan dan pembiayaan serta penyedia semua kebutuhan program tersebut adalah pemerintah.

Faktor pendukung kedua adalah Bidan Desa, dimana bidan lah yang paham seberapa butuh balita tersebut akan gizi. Karena pada dasarnya setiap individu memiliki tingkat kebutuhan gizi yang berbeda. Dengan bidan langsung turun tangan tanpa hanya memantau dan mengandalkan kader PKK, akan membuat pemberian vitamin tepat sasaran.

Faktor pendukung selanjutnya adalah kader PKK. Disini kader PKK sangat berjasa, tanpa mereka program gerakan pengentasan gizi buruk tidak akan dapat berjalan. Karena mereka turun langsung kerumah keluarga balita untuk menjelaskan, menangani serta memantau perkembangan balita yang dikategorikan kurang gizi. 


\section{KESIMPULAN DAN SARAN}

Pelaksanaan Program Gerakan Pengentasan Gizi Buruk cukup efektif dilakukan sebagai upaya memperbaiki gizi bayi dan balita di mnasyarakat. Hal ini tercermin dari besarnya dukungan baik dari masyarakat (paraq ibu) maupun dari petugas kesehatan itu sendiri untuk terus mensosialisasi program GENTASIBU, khususnya di Kelurahan Begadung Kecamatan Nganjuk Kabupaten Nganjuk. Hambatan-hambatan dapat diatasi dengan ketekunan, kesabaran dan kegigihan petugas yang langsung terjun ke lapangan yaitu Bidan Desa dan Kader PKK.

Disarankan kepada PUSKESMAS bahwa sebaiknya ada penambahan petugas gizi pada puskesmas, serta menjadwalkan para ahli gizi untuk mendatangi setiap kegiatan posyandu untuk memantau para balita dan ibu hamil. Dengan seperti itu gizi buruk atau kurang gizi dapat dicegah dan teratasi sejak dini. Karena adanya orang tua yang kurang mengerti, sebaiknya perlu diadakan sosialisasi rutin untuk seluruh orangtua balita tanpa terkecuali. Hal ini bertujuan agar mereka memahami program Gentasibu tanpa merasa dihakimi atau dipaksa.

Disarankan kepada Pak Lurah bahwa dukungan dari kepala kelurahan juga sangat penting, maka dari itu sebaiknya kepala kelurahan ikut serta dalam kegiatan yang berhubungan dengan program Gentasibu. Dengan seperti itu orang balita akan merasa dilindungi.

\section{REFERENSI}

Afan, M. T. 2018. Efektivitas Pelaksanaan Program Gentasibu (Gerakan Pengentasan Gizi Buruk) dalam Upaya Mengatasi Balita Gizi Buruk di Kabupaten Nganjuk (Studi pada Dinas Kesehatan Kabupaten Nganjuk). Universitas Brawijaya.

Agrinadhiar, N. 2011. Efektivitas Pelaksanaan Program Pengentasan Gizi Buruk Di Kabupaten Nganjuk (Studi Tentang Program Gentasibu Pada Dinas Kesehatan Di Kabupaten Nganjuk). Universitas Brawijaya.

Anggito, A., \& Setiawan, J. 2018. Metodologi penelitian kualitatif. CV Jejak (Jejak Publisher).

Astuti, N. M. M. P., \& Dharmadiaksa, I. B. 2014. Pengaruh Efektivitas Penerapan Sistem 
Informasi Akuntansi, Pemanfaatan dan Kesesuaian Tugas pada Kinerja Karyawan. E-Jurnal Akuntansi Universitas Udayana, 9(2), 373-384.

Dunn, W. N. 2015. Public policy analysis. Routledge.

Dye, T. R. 2013. Understanding public policy: Pearson new international edition. Pearson Higher Ed.

Elis Sriani, M., \& Sasmito, C. 2018. Hasil Cek Similarity: Efektivitas Pelayanan Publik Di Bidang Kesehatan Dalam Upaya Mewujudkan Kesejahteraan Masyarakat. Efektivitas Pelayanan Publik Di Bidang Kesehatan Dalam Upaya Mewujudkan Kesejahteraan Masyarakat, 7(2), 49-55.

Karigas, J., Irawanto, I., \& Jamili, M. J. M. 2018. Implementasi Peraturan Bupati Barito Timur Nomor 6 Tahun 2015 Tentang Pengadaan Barang/Jasa Di Desa. Reformasi: Jurnal Ilmiah Ilmu Sosial Dan Ilmu Politik, 7(2).

Kasiram, M. 2010. Metodologi penelitian: Kualitatif-kuantitatif. Uin-Maliki Press.

Martono, N. 2010. Metode penelitian kuantitatif: Analisis Isi dan Analisis Data Sekunder (sampel halaman gratis). RajaGrafindo Persada.

Purwanto, E. A. 2012. Implementasi Kebijakan Publik Konsep dan Aplikasinya di Indonesia (Issue 1). 2012.

Rahmawati, E. 2017. Implementasi Program (Gentasibu) Gerakan Pengentasan Gizi Buruk Di Puskesmas Kecamatan Tanjunganom Kabupaten Nganjuk. Publika, 5(3).

Rian, N. 2017. Public Policy edisi ke 6. Jakarta: Elex Media.

Rijali, A. 2019. Analisis data kualitatif. Alhadharah: Jurnal Ilmu Dakwah, 17(33), 81-95.

Rusydi, I. 2015. Filsafat Politik Islam; Sebuah Pengantar. Risâlah, Jurnal Pendidikan Dan Studi Islam, 2(1), 110-123.

Sahputra, I. H. 2015. Pengaruh Gaya Kepemimpinan Terhadap Efektivitas Proses Belajar Mengajar (Studi Kasus Berdasarkan Persepsi Mahasiswa Angkatan 2014 Fakultas Bisnis dan Manajemen di Universitas Widyatama). Universitas Widyatama.

Saldana. 2014. Qualitative Data Analysis, A Methods Sourcebook. UI-Press.

Setyosari, H. P. 2016. Metode penelitian pendidikan \& pengembangan. Prenada Media.

Suhelmi, A. 2001. Pemikiran Politik Barat. Gramedia Pustaka Utama. 
Wijaya, H. 2019. Analisis Data Kualitatif: Sebuah Tinjauan Teori \& Praktik. Sekolah Tinggi Theologia Jaffray. 